\title{
Pencugan Ibing Penca Topeng Pendul Kabupaten Karawang
}

\author{
Dedi Rosala, Agus Supriyatna, Ace Iwan Suryawan \\ Departemen Pendidikan Seni Tari, Fakultas Pendidikan Seni dan Desain \\ Universitas Pendidikan Indonesia \\ Jalan Dr. Setiabudhi Nomor 229 Bandung, 40154 \\ Email: deros@ymail.com, supriyatnagus_88@upi.edu, aciwans@yahoo.co.id
}

\begin{abstract}
The purpose of the article is to understand pencugan ibing penca style in the Topeng Pendul group leaded by Syahrul in Karawang regency, West Java. The aim of this research is to reveal the richness of dance styles in West Java, and as materials for pencak silat lessons, which are sourced from traditional arts, and are only limited to ibing penca tepak dua and tepak tilu paleredan. The research method uses a qualitative, descriptive method, and valitades data with triangulation techniques. The research findings are: (1) a staging is performed in early scene of a drama containing a historical story; (2) patterns and motions of pencugan ibing penca cannot be separated from the influence of pencak silat styles in West Java; (3) a staging has some elements include time, places, plays, characters, music, song lyrics, and costumes; (4) the function of staging is for an entertainment, respects and pride of the perpetrators of ceremonies to their ancestors, and as the character's amplifier of the main role in the play of a historical story.
\end{abstract}

Keywords: pencugan ibing penca, pendul mask, pencak silat

\begin{abstract}
ABSTRAK
Tujuan artikel ini adalah untuk memahami pencugan ibing penca pada kelompok kesenian Topeng Pendul pimpinan Syahrul di Kabupaten Karawang, Jawa Barat. Alasan penting penelitian ini sebagai upaya pengayaan khasanah seni tari di Jawa Barat, dan sebagai bahan bagi pengembangan bahan ajar Pencak silat yang bersumber seni tradisional, yang selama ini terbatas pada ibing penca tepak dua dan tepak tilu paleredan. Metode penelitian yang digunakan, yaitu penelitian kualitatif yang bersifat deskriptif, dan validasi data dengan cara triangulasi. Temuan penelitian dapat disampaikan sebagai berikut, (1) pementasan dilakukan pada awal adegan, babak lakon bermuatan roman sejarah; (2) pola dan ragam gerak pencugan ibing penca tidak dapat lepas dari pengaruh jurus-jurus aliran pencak silat yang ada di Jawa Barat; (3) pementasan memiliki unsur waktu, tempat, lakon, seni peran, musik, syair lagu, dan rias busana; dan (4) fungsi pementasan sebagai media hiburan estetis, rasa hormat dan bangga bagi yang punya hajat terhadap leluhurnya, dan penguat karakter peran utama dalam lakon roman sejarah.
\end{abstract}

Kata kunci: pencugan ibing penca, topeng pendul, pencak silat 


\section{PENDAHULUAN}

Penelitian ini dilatarbelakangi oleh fenomena seni pertunjukan yang ada di Kabupaten Karawang. Keberadaan seni pertunjukan di Karawang sangat memengaruhi seni jaipongan dan bajidoran. Suwanda mengatakan bahwa "motif-motif tepak kendang jaipongan terinspirasi oleh idiom-idiom kesenian yang telah ada, seperti kiliningan, ketuk tilu, topeng banjet, dan pencak silat" (Mulyana \& Ramlan, 2012: 45; Saepudin, 2013: 22).

Kedua jenis kesenian ini (jaipongan dan bajidoran) menjadi fenomena menarik sebagai kesenian daerah yang sama-sama memiliki masyarakat pendukungnya. Keberadaan kedua jenis kesenian tersebut dalam konteks masyarakat pendukung dimaknai sebagai bagian penting dan tidak bisa lepas dari fungsi seninya. Seni bajidoran dan topeng banjet masih digemari sampai saat ini, terutama seni bajidoran (Wikandia, 2016: 61).

Terkait dengan kebertahanan seni pertunjukan di tengah-tengah masyarakat pemilik dan pendukungnya, Jaeni (2012: 161162) mengatakan:

Tidak sedikit pergelaran seni pertunjukan ditinggalkan oleh penontonnya atau dinilai gagal, baik pertunjukan drama, tari maupun musik, bukan semata karena pertunjukan itu tidak didukung oleh personil yang cantik atau ganteng, perlengkapan seni pertunjukan yang serba modern atau kemegahan panggung yang dahsyat dengan kekuatan tata cahaya dan tata suara yang mengagumkan. Akan tetapi pertunjukan itu gagal dikarenakan tidak mampu memberikan informasi nilai-nilai yang disepakati masyarakatnya. Pertunjukan tidak mampu 'mengomunikasikan' bentuk estetis melalui tindakan-tindakan simbolik yang masyarakat anut dan dipahami lingkungannya.

Topeng banjet di Kabupaten Karawang memiliki akar sejarah cukup tua dan tetap berupaya memertahankan bentuk aslinya. Terkait dengan hal tersebut, Hamid (dalam Supriyatna, 2010: 63) mengatakan:
Kesenian Topeng Banjet yang hidup di Karawang bentuk penyajiannya hampir mendekati tahun 1920-an masih dipertahankan oleh grup Bang Pendul dari Kecamatan Rawamerta, sejak 1993 menjadi Kecamatan Tempuran dan sekarang menjadi Cilamaya Kulon.

Grup Topeng Banjet "Bang Pendul" hingga kini termasuk pada generasi keempat. Keberadaan kelompok seni ini tetap bertahan dan masih menyimpan bentuk seni sesuai aslinya sebagaimana tercermin dalam beberapa unsur pembentuk seninya. Hal ini terutama tampak pada struktur dan unsur tari (pencugan ibing penca) pada penyajian babak lakon Topeng Banjet Pendul Putra.

Subjek dan lokasi penelitian terletak di Dusun Darangdang, Kelurahan Bayur Kidul, Kecamatan Cilamaya Kulon, Kabupaten Karawang. Pemilihan lokasi penelitian ini disebabkan oleh beberapa alasan. Pertama, pemenuhan rasa penasaran peneliti dalam upaya memahami data yang rentan generasi kepemilikannya karena pelaku seninya rata-rata berusia tua. Pencugan pada kesenian topeng banjet mampu memengaruhi penciptaan tari jaipong.

Struktur koreografi tari jaipong dibangun oleh empat fase ragam gerak, yaitu; bukaan, pencugan, nibakeun, dan mincig. Pencugan yaitu fase ragam gerak yang lebih merupakan permainan jurus yang sudah distilasi untuk kebutuhan tari (gerak ini bisa dilakukan di tempat maupun berpindah tempat), lazimnya disebut gerak pokok atau ibing pola, misalnya, besot, siku, bandul, tajong, jérété, peupeuh, dan sebagainya. (Mulyana \& Ramlan, 2012: 42)

Kedua, kelompok kesenian Topeng Pendul yang kini dipimpin Syahrul Pendul Putra merupakan generasi pertama dari Bah Jalam (2015), generasi ketiga dari Bah Pendul (1984), dan generasi keempat sepeninggal Bah Sairan, (1939) dapat dikatakan masih kental dengan nilai-nilai tradisi, bermuatan nilai sejarah yang cukup tua dan tetap eksis di tengah-tengah ma- 
syarakat pendukungnya. Tidak dimungkiri dalam perjalanannya terjadi perubahan dan alih generasi kepemilikan (pelaku) seni tersebut. Suwanda (dalam Saepudin, 2013: 20) menjelaskan bahwa:

Sejak tahun 1966 sampai dengan 1977, Suwanda mencari ilmu dalam grup-grup Topéng Banjét di Karawang, seperti grup Topéng Banjét Abah Reman, Abah Pendul, Wadas, Baskom, Ali Saban, dan terakhir group Tanjidor.

Ketiga, penelitian terhadap pencugan ibing penca pada kesenian Topeng Pendul secara khusus sebagai upaya pemberdayaan seni berbasis kearifan lokal untuk pengayaan materi seni tari di Jawa Barat, dan suplemen bahan ajar Pencak silat yang cenderung terbatas pada materi ibing penca tepak dua dan tepak tilu paleredan pada Mahasiswa Departemen Pendidikan Seni Tari, FPSD UPI.

Berdasarkan latar belakang, penelitian ini memiliki tujuan untuk memahami pertunjukan lakon, pola dan ragam, unsur dan fungsi pencugan ibing penca pada kesenian topeng banjet pimpinan Syahrul Pendul Putra Kabupaten Karawang.

Penelitian kesenian topeng banjet ini merupakan penelitian lanjutan yang dilakukan peneliti (Supriyatna, 1996 dan 2010) dan Iramaya, Rosala, Supriyatna (2015) pada kesenian topeng pendul di Kabupaten Karawang dengan catatan belum membahas secara khusus dan mendalam terkait pencugan ibing penca pada pertunjukan topeng pendul di Kabupaten Karawang.

Berikut ini, peneliti mengemukakan bentuk pertunjukan topeng banjet secara umum dengan mengacu pada pendapat Martasasmita (Supriyatna, 2010: 81).

Dari zaman dahulu sampai sekarang tidak berubah-ubah (bersifat tradisi, tetap, turun temurun) hanya cara dan gayanya menampilkan yang berbeda, dengan urutan; (1) tabuh permulaan; (tatalu) dari dahulu sampai sekarang tetap memakai arang-arangan. (2) Lagu permulaan, dahulu dengan lagu gonjingan. (3) Ronggeng keluar, melagu dan menari. Dari dahulu sampai sekarang memakai lagu lipet gandes. (4) Pelawak keluar, menari dan melawak, dahulu lagu sekoci, ketuk tilu, seperti gaplek atau kangsreng. (5) Tarian bersama (Ronggeng dan penari pria). Dahulu penari prianya orang-orang luar (penonton yang menari). Dari tahun 50-an penari prianya juga dari rombongan (6) Melawak, dahulu memakai tiga macam lawakan ialah ngarung, ngagones dan nyetro (7) Pentasan lelakon, dahulu di samping lelakon pendek, menggambarkan kehidupan masyarakat Karawang, Bekasi, dan Jakarta, beserta jawara-jawara.

Sumber lain, terkait lakon pada topeng banjet, dikemukakan Sembung (dalam Supriyatna, 2010: 102):

Pada umumnya cerita-cerita Topeng Banjet berasal dari cerita-cerita rakyat yang berbau sejarah. Sebagai manifestasi kehidupan mereka sehari-hari. Temanya berkisar pada kehidupan rumah tangga, kriminalitas, kekejaman, dan kemalangan, serta kelakuan-kelakuan yang tidak dapat diterima oleh masyarakat.

Sumber terhadap kajian pencugan ibing penca Topeng Pendul Kabupaten Karawang dengan kandungan jurus atau gerak aliran pencak silat dan ibing pencak di Jawa Barat mengacu pada pendapat Kuswandi (2014) dan Wikipédia (2016), sebagai berikut.

Jurus Silat Cimande memiliki kekhasan jurus di dalamnya, utamanya; jurus kelid dan jurus pepedangan Cimande. Jurus kelid Cimande; di dalamnya terdapat jurus; serong panggul dan beulit kacang.

Adapun sumber gerak dasar maenpo Cikalong terdiri atas (1) jurus, (2) pancer, (3) tangtungan, (4) pasangan dan sambutan (R.H.O. Soleh, 2010: 61-153).

Gerak atau jurus silat dari ibing pencak tepak dua dan tepak tilu paleredan dapat dikatakan:

Jurus tepak dua paleredan dengan jurus kudakuda serong (langkah kaki kiri, langkah kaki kanan, pasang tangan kanan serong kiri). Sogok, giles, sodok jambret, gejlig, peupeuh, sogok. Jurus tepak tilu paleredan dengan jurus langkah kaki kanan, kiri, pasang (kedua 
lengan di depan dada), gunting (kaki dibuka sejajar), kelid, giles, sogok, peupeuh, gejlig, dan loncat. (Kasmahidayat \& Sumiati, 2010: 29-34)

Seni dalam hubungan sebagai entitas masyarakat, termasuk di dalamnya keberadaan topeng banjet tetap memiliki fungsi, baik sebagai pelengkap maupun pendukung di tengah-tengah masyarakatnya. Hal itu sebagaimana dikemukakan Danandjaya (dalam Supriyatna, 2010: 123),

\begin{abstract}
Masyarakat penyangga adalah masyarakat yang dibentuk oleh tatanan masyarakat luas sebagai penyangga nilai-nilai luhur adat istiadat setempat secara akar tradisi. Sedangkan masyarakat pewaris adalah masyarakat pelaku seni yang mewarisi bentuk dan jenis pertunjukan sebagai amanah atau titipan orang tua (leluhur) berupa perilaku dan keterampilan seni yang perlu untuk dijaga dan dikembangkan sepanjang memberi manfaat kepada bagi kehidupan masyarakat penyangganya.
\end{abstract}

Untuk mencapai tujuan penelitian, peneliti berupaya untuk memperoleh sejumlah data yang diperlukan melalui suatu pendekatan dan metode penelitian sesuai kebutuhan penelitian.

Penelitian terhadap pencugan ibing penca Topeng Pendul Kabupaten Karawang menggunakan pendekatan kualitatif dengan metode deskriptif, yakni untuk memaparkan sejumlah data hasil penelitian melalui tahapan pengumpulan data, pengelompokan data, analisis data, pemaparan data, dan simpulan data penelitian, sehingga menjadi suatu gambaran penelitian.

Terkait dengan partisipan dan lokasi penelitian, peneliti mengacu pada pendapat Milles dan Huberman (dalam Creswell, 2010: 267). Ia menjelaskan sebagai berikut.

Ada empat aspek terkait partisipan dan lokasi penelitian. (1) Setting (lokasi penelitian), (2) Aktor (siapa yang akan diobservasi atau diwawancarai), (3) Peristiwa (kejadian apa saja yang dirasakan oleh aktor yang akan dijadikan topik wawancara dan observasi), (4) Proses (sifat peristiwa yang dirasakan oleh aktor dalam setting penelitian.
Adapun teknik validasi data dalam penelitian mengacu pada pendapat Hopkins (dalam Creswell, 2010: 286). Ia mengungkapkan bahwa "Triangulasi, pengecekan kebenaran data tentang pelaksanaan penelitian dengan cara mengkonfirmasikan kebenaran data kepada narasumber."

Penelitian dengan fokus pada pencugan ibing penca Topeng Pendul pimpinan Syahrul Pendul Putra di Kabupaten Karawang ini diharapkan dapat berkontribusi sebagai masukan kebijakan bagi lembaga pendidikan dan dinas terkait serta menjadi temuan suplemen bahan ajar seni tari untuk para guru di sekolah formal dan nonformal dalam upaya pengayaan materi ibing penca di Jawa Barat, dan Indonesia pada umumnya.

\section{METODE}

Penelitian terhadap pencugan ibing penca Topeng Pendul pimpinan Syahrul Pendul Putra di Kabupaten Karawang bersifat kualitatif dengan metode penelitian deskriptif. Data penelitian diperoleh melalui penelitian lapangan melalui teknik pengumpulan data berupa observasi langsung, pendokumentasian, kajian pustaka, dan wawancara dengan narasumber, yakni Sangkun Taryana (sesepuh, dalang topeng, pemeran tokoh, 73 tahun) dan Suhayati (pelatih tari, penari topeng, dan pemeran tokoh, 62 tahun) sebagai pelaku seni Topeng Pendul sejak Bah Pendul masih hidup sampai sekarang.

Prosedur penelitian dilakukan melalui sejumlah tahapan, pengumpulan data dilakukan dengan pencatatan selama penelitian dari tanggal 26 Agustus sampai dengan 28 Agustus 2016, menggunakan alat pengumpul data dalam bentuk pedoman, berupa observasi, wawancara tidak terstruktur, dan dokumentasi dalam bentuk foto. Pengolahan data dilakukan dengan cara kategorisasi data lapangan dalam bentuk deskripsi hasil penelitian, pembuatan tabel, dan dokumentasi foto, yang kemu- 
dian dianalisis dengan teori yang relevan terkait struktur pertunjukan lakon, pola dan ragam jurus, unsur, fungsi dan analisis pengaruh aliran pencak silat di Jawa Barat sehingga menjadi suatu gambaran hasil penelitian pencugan ibing penca Topeng Banjet pimpinan Syahrul Pendul Putra di Kabupaten Karawang. Untuk menjaga keakuratan temuan data penelitian, validasi data dilakukan dengan cara triangulasi, yakni melakukan konfirmasi terkait hasil penelitian, antara tim peneliti dan narasumber.

\section{HASIL DAN PEMBAHASAN}

Topeng Pendul berdiri sejak 1912 dipimpin oleh Bah Sairan dengan nama grup dari awal pendirian sampai sekarang bernama "Sinar Pusaka Warna". Sepeninggal Bah Sairan, kelompok seni diteruskan oleh putranya bernama Asmu alias Bang Pendul. Bah Asmu meninggal, H. Jalam Pendul Putra selaku anak Bah Asmu meneruskan kelompok seni ini sampai tutup usia tahun 2015. Sepeninggal H. Jalam Pendul Putra, grup kesenian Topeng Pendul terpecah menjadi dua kelompok; Pendul Satu dan Pendul Dua. Topeng Pendul Satu dipimpin oleh Bapak Jaya, anak dari istri pertama $\mathrm{H}$. Jalam Pendul Putra berdomisili di Dusun Bayur, Kelurahan Bayur Lor, Kecamatan Cilamaya Kulon, Kabupaten Karawang. Topeng Pendul Dua dipimpin oleh Bapak Syahrul anak dari istri kedua almarhum $\mathrm{H}$. Jalam Pendul Putra bertempat di Dusun Darangdang, Kelurahan Bayur Kidul, Kecamatan Cilamaya Kulon, Kabupaten Karawang.

Akibat pecahnya kelompok Topeng Pendul ini berdampak pada kesinambungan dan perubahan bentuk pertunjukan Topeng Pendul. Kelompok Topeng Pendul pimpinan Syahrul masih kukuh memertahankan bentuk pertunjukan Topeng Banjet mendekati aslinya. Kelompok Topeng Pendul Dua, pimpinan Bapak Syahrul didukung oleh para anggota senior penerus dari H. Jalam Pendul Putra. Sedangkan Topeng Pendul Satu pimpinan Bapak Jaya didukung oleh para pemula dan kawula muda, sehingga kemungkinan besar terjadi perubahan bentuk dengan hilangnya beberapa unsur pertunjukan dari kekhasan Topeng Pendul.

Taryana dan Suhayati (wawancara, 26 Agustus 2016) mengatakan sebagai berikut.

Pertunjukan Topeng Abah masih tetap dipertahankan; (1) Tabuh permulaan (tatalu panjang dan pendek) dengan memakai lagu arang-arangan, yakni musik instrumentalia yang bersifat khas iringan topeng banjet dengan cara memainkan rebab. (2) Lagu permulaan lagu Kidung dan lagu Gonjingan. (3) Ronggeng keluar, menyanyi dengan syair "pantun aileu "dan menari dengan memakai iringan lipet gandes. (4) Pelawak keluar terjadi komunikasi antara pelawak dan penari topeng dalam lagu sakoci, enjotenjotan dan lagu ucing-ucingan dengan memakai tiga macam lawakan yaitu: ngarung, ngagones, dan nyetro. (5) Pementasan lakon, diawali dengan lagu trembel dan ibing penca dalam kisah roman sejarah dan atau roman keluarga menggambarkan kehidupan masyarakat Karawang beserta para Jawara. (6) Lagu penutup, carecet beureum.

Berdasarkan analisis struktur dan unsur pembentuk seni Topeng Banjet menurut pendapat Martasasmita dan Topeng Pendul pimpinan Syahrul di Kabupaten Karawang, dapat dikatakan masih memertahankan dan menyimpan bentuk pertunjukan sesuai aslinya.

Pertunjukannya bersifat khusus dan tertentu, yakni pada pertunjukan babak lakon dengan kisah roman sejarah. Artinya, tidak selalu pertunjukan Topeng Pendul yang dibawakan oleh para pelakunya menampilkan pencugan ibing penca pada babak pertunjukan lakon.

\section{Pertunjukan Lakon Topeng Pendul}

Lakon dalam pertunjukan Topeng Banjet merupakan unsur pelengkap dari keseluruhan pertunjukan Topeng Pendul. Pertunjukan Topeng Pendul tidak selalu mementaskan unsur lakon. Lain halnya 
dengan penyajian; ngukus, tatalu pondok, tari topeng atau tari lipet gandes (pantun aileu) dan lagu penutup carecet beureum menjadi struktur dan unsur penting dalam pertunjukan Topeng Pendul.

Lebih lanjut terkait dengan unsur lagu dalam penyajian lakon pada awal babak adegan lakon, Taryana (wawancara, 27 Agustus 2016) menjelaskan.

Lagu trembel merupakan perpaduan syair lagu dan tabuhan musik berirama kliningan dibawakan oleh Juru Sinden. Penyajian lagu trembel berfungsi sebagai interval atau waktu antara (panyelang) para pemeran dalam mempersiapkan pementasan lakon. Waktu jeda ini menjadi kesempatan para pemeran lakon untuk berganti kostum, merias wajah, menyiapkan peralatan pentas lakon. Durasi penyajian lagu trembel pada babak lakon dapat memakan waktu kurang lebih 10 menit. Dengan syair lagu bertemakan pantun nasihat dan sindiran serta penyebutan nama para simpatisan Topeng Pendul.

Usai penyajian lagu trembel disambung dengan pengantar atau prolog yang disampaikan oleh dalang topeng, dibawakan oleh Sangkun Taryana. Informasi yang disampaikan oleh dalang topeng biasanya mengenai maksud diselenggarakan pertunjukan oleh punya hajat (shohibulbet), lakon cerita yang akan digelar, dan permohonan maaf dari pihak rombongan Topeng Pendul. Permohonan maaf dimaksud manakala dalam pementasan lakon ada nama yang disebut, tempat atau pun kedudukan para pejabat pemerintah serta lakon kurang memuaskan para penonton. Setelah pengantar lakon dibawakan oleh dalang topeng, mulailah dengan pertunjukan lakon.

Pertunjukan lakon Topeng Pendul, salah satunya lakon Pa Abrag. Lakon ini memiliki pola, struktur, susunan unsur seni mulai dari babak awal, babak isi (tengah), dan babak akhir. Pada penyajian babak awal, pada bagian introduksi, dengan iringan musik dan syair lagu berisi sisindiran bernuansa musik kliningan sebagai pengantar tokoh masuk arena pentas. Ti- dak lama, musik beralih pada irama tepak kendang penca tanpa menggunakan instrumen terompet mengiringi pemeran utama menampilkan keterampilan pencugan ibing penca. Waditra atau peralatan gamelan dan syair lagu yang digunakan, terdiri atas: kendang, goong anggog, ketuk, kecrek, dan rebab dengan syair lagu berbahasa melayu gaya Jakartaan.

Pemeran tokoh usai menampilkan keterampilan ibing penca dengan beberapa jurus silat dengan tanda pukulan goong sampai gerak mincid (lalayangan) dan musik pun berhenti. Jelang beberapa saat adegan beralih pada percakapan dengan penonton (aside) sebagai adegan pengenalan tokoh yang diperankan. Adegan awal babak pertama berupa paparan gambaran tokoh hitam atau putih dengan penyampaian visi dan misi melalui peran tokoh yang dibawakan. Penyampaian visi dan misi yang disampaikan melalui prolog, berisi keterangan singkat lakon yang akan dipentaskan di mana tempat kejadiannya, siapa saja pelakunya, siapa yang menjadi tokoh utamanya, dan bagaimana lakon akan berakhir.

Pada pertunjukan lakon Pa Abrag, adegan awal lakon dibuka dengan ucapan permohonan maaf, manakala terjadi kekeliruan atau kekhilafan dalam urutan cerita yang akan dipentaskan. Hal ini dilakukan agar tidak terjadi penuntutan dari pihak yang punya hajat atau para keturunan yang mengetahui dan pernah terlibat dalam lakon yang akan dipentaskan (Wawancara Taryana, 28 Agustus 2016).

Dialog mengenai dirinya sendiri dengan kesombongan-kesombongan para tokoh menjadi pemicu dalam mengembangkan irama dramatik dari suatu adegan. Suasana adegan berkembang dan menjadi hidup karena dialog yang dibicarakan cukup ironis dan menyindir dirinya sendiri serta memancing datangnya tokoh lain dalam mengembangkan cerita dalam suatu adegan. 
Pertunjukan babak lakon Topeng Pendul dapat memakan waktu 3 (tiga) jam, mulai pukul 00.30 WIB. sampai dengan pukul 03.00 WIB. Setelah pertunjukan lakon Topeng Pendul selesai disajikan, kemudian pertunjukan berikutnya beerupa ungkapan kata-kata penutup yang disampaikan oleh dalang topeng.

Struktur pertunjukan Topeng Pendul berikutnya yaitu penyajian lagu carecet beureum. Lagu ini dibawakan oleh seorang sinden, diiringi irama musik ketuk tilu disajikan selama kurang lebih 5 (lima) menit. Syair lagu carecet beureum berupa syair pantun nasihat dengan pesan bahwa "setiap pertemuan akan berakhir dengan perpisahan, tanamkan kebaikan dan jagalah persaudaraan."

\section{Pencugan Ibing Penca}

Pencak silat lebih populer di Jawa Barat dengan sebutan ibing pencak silat. Namun, tidak sedikit orang menyebut seni pencak silat ini dengan istilah tari pencak silat. Padahal dalam kenyataannya, istilah ibing pencak silat dengan istilah tari pencak silat mempunyai pengertian berbeda. Ibing pencak silat mempunyai pengertian yang lebih mendalam dibandingkan dengan tari pencak silat, karena dalam ibing pencak silat selain ada unsur keindahan gerak di dalamnya, juga mempunyai tujuan akhir menjatuhkan lawan. Karenanya, dalam ibing pencak silat unsur bela diri lebih menonjol. Sedangkan istilah tari lebih ditekankan pada unsur keindahannya saja, tidak ada unsur bela diri, seperti tari-tarian yang sering kita lihat. Oleh karena itu, rasanya kurang tepat apabila pencak silat disebut sebagai tari pencak silat, sebab pada umumnya para ahli pencak silat di Jawa Barat menyebut seni pencak silat dengan sebutan ibing pencak silat bukan tari pencak silat.

Pada mulanya, pencak silat lahir karena kebutuhan masyarakat untuk memertahankan diri, maka dapat dipahami kalau aspek yang menonjol adalah aspek bela diri. Namun, pada kurun waktu tertentu situasi politik pada saat itu (zaman penjajahan Belanda) tidak begitu respek terhadap bela diri (pencak silat). Maka pengembangan pencak silat beralih dari aspek bela diri ke aspek seni. Hal ini merupakan salah satu taktik dari para pendekar pencak silat untuk tetap melestarikan pencak silat. Padahal jika diperhatikan lebih seksama, justru dalam seni pencak silat tersembunyi kaidah bela diri pencak silat.

Di Jawa Barat, di samping dikenal aspek bela diri yang lebih akrab disebut buah atau eusi, dikenal pula pencak silat, seni yang disebut kembang atau ibing pencak silat. Apabila mendengar kata "pencak", maka yang terbayang oleh masyarakat Jawa Barat bukanlah suatu sistem pembelaan diri, melainkan suatu seni ibing pencak silat yang diambil dari gerak serangan dan belaan. Ada beberapa unsur yang perlu diperhatikan dalam ibing pencak silat, antara lain sebagai berikut.

Pertama, unsur kekayaan gerak (wiraga), yaitu kekayaan gerak atau jurus-jurus yang dimiliki oleh seorang pesilat selama belajar di perguruannya. Penampilannya menjadi tidak monoton atau membosankan apabila tampil di atas pentas (terutama dalam pertandingan seni pencak silat). Akan tetapi, apabila dalam kaulan (spontanitas) pada acara hajatan, unsur kekayaan geraknya tidak begitu diperhatikan pesilat. Bagi pesilat dalam membawakan ibingannya, yang penting adalah mampu memperagakan gerakannya dengan baik dan benar sesuai dengan kaidah pencak silat karena tidak terikat oleh sistem penilaian dari juri seperti dalam pelaksanaan pertandingan seni pencak silat.

Kedua, unsur irama (wirahma) atau musik, unsur inilah yang membedakan aspek seni dengan aspek yang lain dalam pencak silat. Kendang pencak merupakan sejenis alat musik tradisional yang biasa dipakai mengiringi pesilat yang tampil di atas panggung dan alat tradisional ini 
sering digunakan dalam pertandingan seni pencak silat, dan acara khitanan atau acara kesenian daerah lainnya. Daerah-daerah yang masih menggunakan peralatan musik tradisional ini di antaranya daerah Bogor, Sukabumi, Bandung, Cianjur, Garut, dan banyak lagi daerah lainnya di Jawa Barat.

Ketiga, unsur penjiwaan gerak (wirasa), yaitu salah satu unsur yang sangat penting dimiliki oleh seorang pesilat karena penjiwaan gerak ini sulit dipelajari dan dipahami pesilat, di samping juga memerlukan waktu yang cukup lama. Penjiwaan gerak merupakan salah satu unsur yang mempunyai nilai seni bela diri tinggi dalam seni pencak silat. Oleh karena itu, pesilat dituntut harus menguasai arti dan makna jurus pencak silat yang sebenarnya, serta mengerti maksud dan tujuan dari jurus-jurus dan teknik-teknik pencak silat yang dipelajari.

Mencermati dan memahami istilah "pencugan" dalam gerak, baik dalam jurus atau gerak ibing pencak maupun dalam gerak tari jaipong yang ada di tatar Sunda, sudah tentu akan menemukan beraneka ragam pemikiran dan pandangan yang berbeda-beda. Perbedaan itu pada umumnya dilatarbelakangi oleh ketiadaan dan ketidakjelasan definisi yang melingkupi istilah pencugan tersebut. Pencugan dalam persepsi yang ada adalah sekumpulan atau rangkaian gerak atau jurus yang dilakukan lebih dari dua gerakan dalam penampilannya.

Berdasarkan hasil penelitian yang dilakukan mengenai pencugan ibing penca pada kesenian Topeng Pendul, jurus ibing penca merupakan jurus inti atau gerak dasar bagi setiap pemeran yang akan membawakan peran tokoh, terutama sebagai tokoh yang mengembangkan alur cerita dari lakon yang disajikan. Pencugan ibing penca Topeng Pendul berpangkal pada keselarasan, keseimbangan, dan keserasian antara wiraga, wirahma, dan wirasa para penampilnya. Jurus-jurus ibing penca yang ditampilkan diiringi dengan musik pengiring yang khas dan dipergelarkan pada acara-acara kegiatan sosial seperti pesta panen, perkawinan, khitanan, dan keramaian umum.

\section{Pola dan Ragam Pencugan Ibing Penca Topeng Pendul}

Pada dasarnya ibing penca pada kesenian Topeng Pendul disajikan oleh pemeran tokoh dari suatu lakon yang dibawakan, baik tokoh protagonis ataupun tokoh antagonis.

Pola dan ragam jurus atau gerak pencugan ibing penca Topeng Pendul pimpinan Bapak Syahrul berdasarkan temuan peneliti dapat dikemukakan.

Pola dan ragam pencugan ibing penca Topeng Pendul penyajiannya dapat dibagi dalam lima pola. Pola bukaan (pola satu), pola dua, tiga dan empat (pola isi) dan pola lima (pola penutup). Masing-masing gerak atau jurus pencak dalam penyajiannya bersifat tidak tetap, diulang dan terjadi pengembangan secara spontan oleh penari atau tokoh yang membawakan peran tokoh hitam (jahat) dan atau tokoh putih (tokoh utama), yang penting jurus-jurus ibing penca tersebut kena atau jatuh pada pukulan goong.

Lebih lanjut Taryana dan Suhayati (wawancara, 27 Agustus 2016), menyatakan sebagai berikut.

Ibing penca yang terdapat pada babak pertunjukan lakon Topeng, sejak Abah masih hidup memiliki jurus-jurus penca bersifat khas yang penting jurus ibing penca mencug atau jatuh pada pukulan goong, tabuh iringan dan alat gamelan yang digunakan tetap sama sebagaimana diajarkan Abah dan Ma Icem (istrinya Bah Endul alias Bah Asmu) kepada Suhayati, istri Dalang Sangkun.

Hadirnya jurus-jurus pencak pada kesenian Topeng Pendul berfungsi untuk memperkuat karakter tokoh peran yang dibawakan sebagai tokoh utama dan atau tokoh jahat, yang disimbolkan dengan ilmu kekebalan tubuh, kadugalan, dan kejawaraan para pendekar dalam membela kebenaran dan rakyat kecil dalam melakukan perkelahian di masa genting atau musim begal ketika tahun 40 -an.

Pola dan ragam pencugan ibing penca dapat dilihat pada tabel 1 . 
Tabel 1. Pola dan ragam pencugan ibing penca Topeng Pendul pimpinan Syahrul Kabupaten Karawang, (Dokumentasi peneliti, 27 Agustus 2016)

\begin{tabular}{ccc}
\hline No. & Pola dan Ragam Pencugan Ibing Penca \\
\hline 1 & Pola satu atau pola bukaan Jurus: Kuda-kuda langkah 1,2 dan 3, gebrag dua kaki dan pa-
\end{tabular}
atau pola awal. sang sogok kiri.

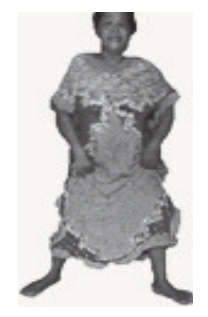

Gambar 1. Jurus kuda-kuda

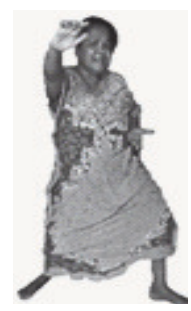

Gambar 2. Jurus pasang sogok

2 Pola dua atau pola tengah. Jurus: Pasang sogok kiri, giles, rogok, meulit kacang, giwar, dan pasang nanggeuy.

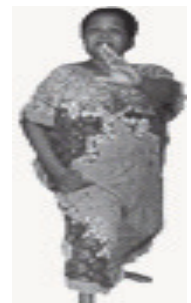

Gambar 3. Jurus pasang sogok

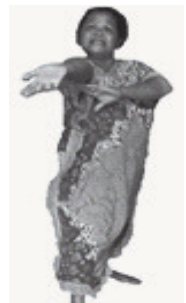

Gambar 6. Jurus meulit kacang

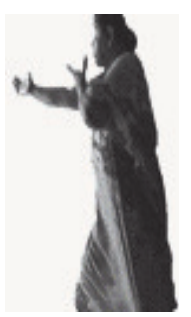

Gambar 4. Jurus giles

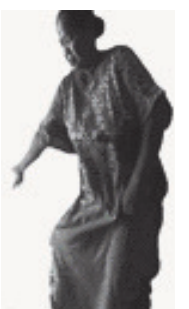

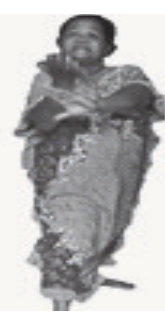

Gambar 5. Jurus rogok

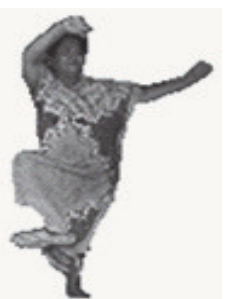

Gambar 7.Jurus gizuar tangan kanan Gambar 8. Jurus pasang nanggeuy

Jurus: Pasang sogok kiri, silang tangkis, lipat potong peupeuh bawah, pasang sogok, giwar tangan kiri, peupeuh tangan kiri, guntingan, peupeuh dua tangan dan pasang sogok.
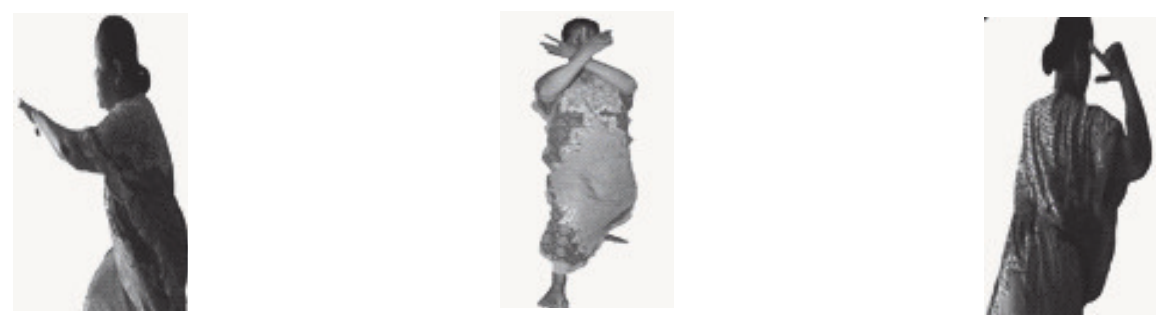

Gambar 9. Jurus pasang sogok Gambar 10. Jurus silang tangkis Gambar 11. Jurus lipat potong pukul bawah 
Tabel 1. Pola dan ragam pencugan ibing penca Topeng Pendul pimpinan Syahrul Kabupaten Karawang, (Dokumentasi peneliti, 27 Agustus 2016) (lanjutan)

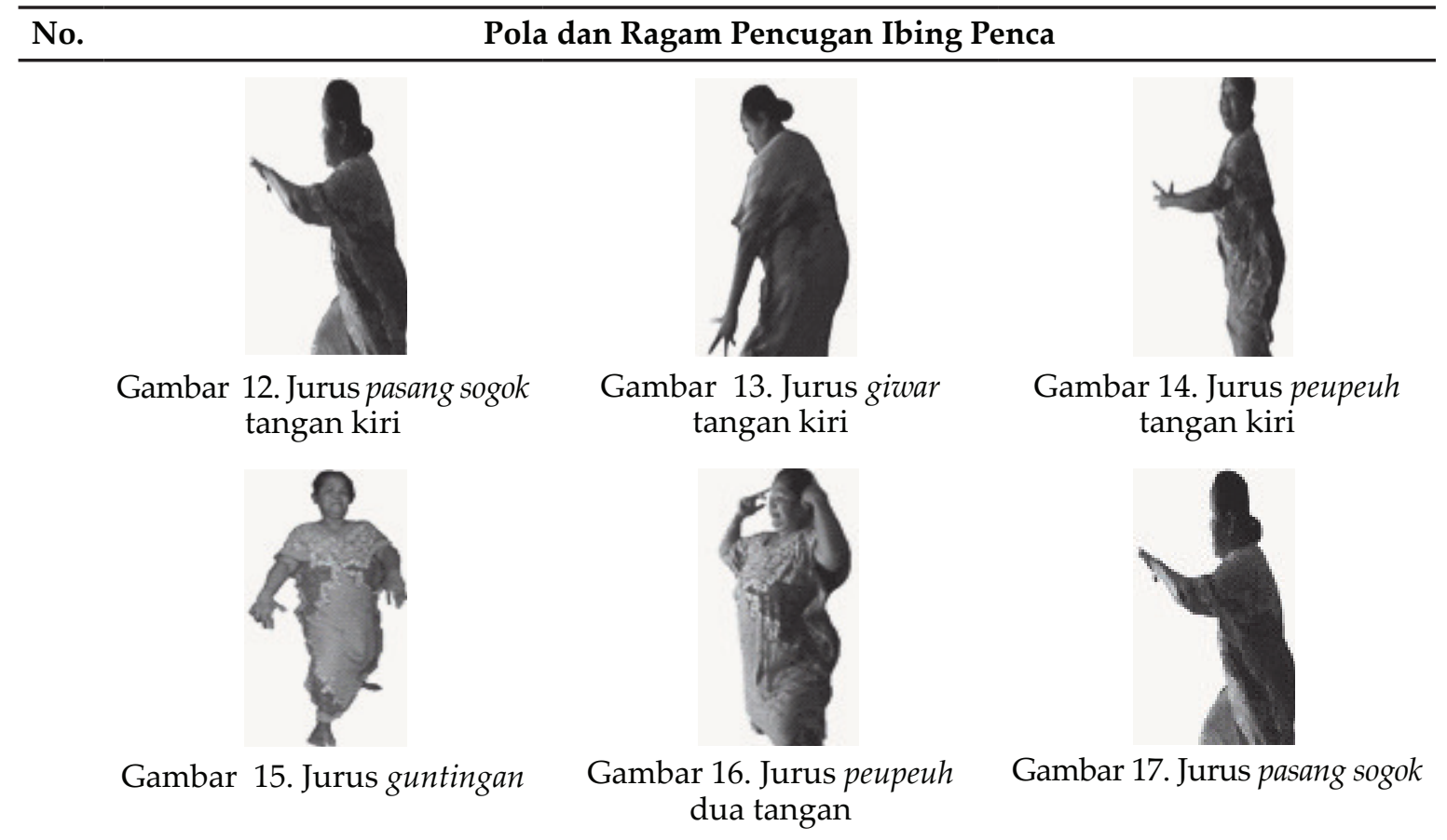

4 Pola empat atau pola tengah. Jurus: pasang sogok kanan, pasang sogok kiri, rogok, jambret, luncat malik/ kelid, dan pasang tungkup.

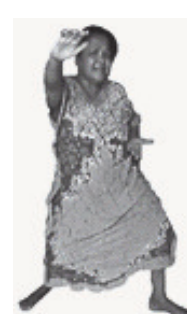

Gambar 18. Jurus pasang sogok kiri pasang sogok kanan

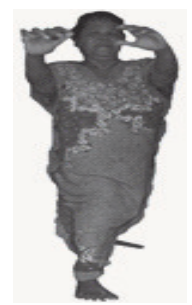

Gambar 21. Jurus jambret

5 Pola lima atau pola akhir atau pola penutup.

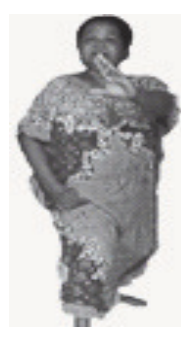

Gambar 24. Jurus pasang sogok kiri

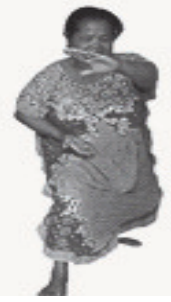

Gambar 19. Jurus pasang sogok kiri

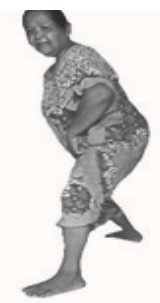

Gambar 22. Jurus luncat malik

Jurus: Pasang sogok kiri, rogok, meulit kacang, geblig kaki kanan, giwar dan pasang nanggeuy.

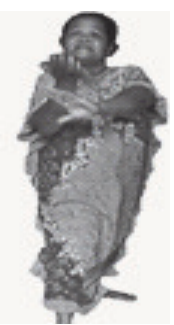

Gambar 25. Jurus rogok
Gambar 23. Jurus pasang bukaan Tungkup
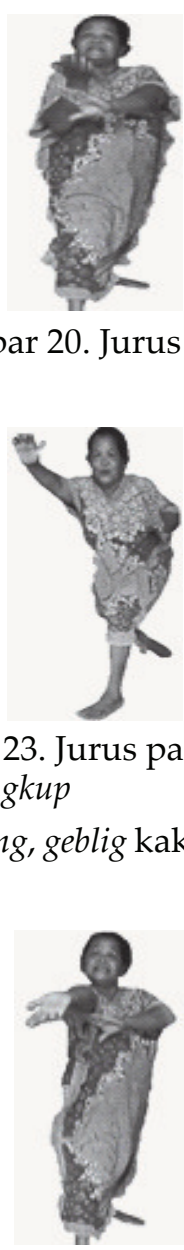

Gambar 20. Jurus rogok

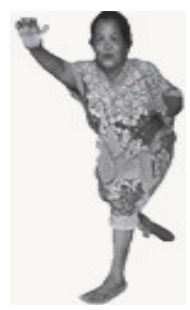

Gambar 26. Jurus meulit kacang 
Tabel 1. Pola dan ragam pencugan ibing penca Topeng Pendul pimpinan Syahrul Kabupaten Karawang, (Dokumentasi peneliti, 27 Agustus 2016) (lanjutan)

\begin{tabular}{ll}
\hline Pola dan Ragam Pencugan Ibing Penca \\
\hline \\
Gambar 27. Jurus geblig & $\begin{array}{c}\text { Gambar 28. Jurus giwar } \\
\text { tangan kanan }\end{array}$ \\
\hline
\end{tabular}

Pola bukaan atau pola awal atau pola satu, terdiri atas jurus atau gerak; $k u d a-k u d a$ langkah 1, 2, dan 3, gebrag dan pasang sogok. Dengan uraian jurus atau gerak dimulai dari kuda-kuda langkah kaki maju serong atau masekon kaki kiri, kaki kanan dan kembali kaki kiri dengan posisi kedua tangan menempel paha, selanjutnya jurus gebrag atau lompat atas dua kaki dan diakhiri dengan gerak mencug (gerak bebas ibing penca saat pukulan goong), pasang sogok tangan kanan, posisi tangan kiri terbuka menempel pinggang, sementara posisi kaki kiri berada di depan serong, kaki kanan di belakang dan posisi tubuh membungkuk ke depan.

Pola isi atau pola tengah atau pola dua pencugan ibing pencak, terdiri atas jurus pasang sogok, giles, rogok, meulit kacang, giwar, dan pasang nanggeuy. Dengan uraian jurus dimulai dari pasang sogok merupakan gerak pasang posisi tangan kiri menempel paha, tangan kanan depan terbuka telungkup dan posisi kaki kanan di depan lurus dan kaki kiri lurus di belakang. Giles merupakan gerak tangan kiri bergerak ke depan bersamaan dengan gerak tangan kanan mundur ke belakang. Rogok, gerakan tangan mundur ke belakang langsung bergerak ke depan seolah-olah menusuk lurus (rogok). Meulit kacang merupakan jurus peralihan tangan rogok ditarik melipat ke belakang, tangan kiri dibuka lurus dada, tangan kiri dibuka lurus dada ke samping. Giwar, gerak tangkisan tangan kanan ke bawah untuk menangkis tendangan kaki. Tangkisan kanan tersebut mengarah dari dalam ke luar. Pasang nanggeuy, gerak pasang dengan posisi tubuh tegak dan kedua tangan terbuka seolah memikul beban dan posisi kaki kanan ditekuk ngambang serong dan posisi kaki kiri tegak lurus menapak tanah.

Pola isi atau pola tengah selanjutnya disebut pola tiga pencugan ibing penca, terdiri atas jurus pasang sogok, silang tangkis, lipat potong peupeuh bawah, pasang sogok, giwar tangan kiri, peupeuh tangan kiri, guntingan, peupeuh dua tangan, dan pasang sogok.

Uraian jurus dimulai dari pasang sogok, gerak kaki kuda-kuda kanan depan, kaki kiri di belakang, posisi badan doyong depan, dan posisi tangan kiri menusuk telungkup dan tangan kiri terbuka disimpan di pinggang. Silang tangkis, tangkisan dua tangan dilakukan dengan menyilangkang tangan kanan dan kiri di depan kepala kemudian dikibaskan ke bawah bersamaan untuk menangkis serangan lawan. Lipat potong, gerak menarik badan ke samping bersamaan dengan tangan kanan dilipat di pundak dan kaki kiri mundur ke belakang dan kaki kiri di depan kemudian tangan kanan dipukulkan ke bawah. Pasang sogok, gerak kaki kuda-kuda kanan depan, kaki kiri di belakang, posisi badan doyong ke depan, 
dan posisi tangan kiri menusuk telungkup dan tangan kiri terbuka disimpan di pinggang. Giwar tangan kiri, gerak tangan kiri diayunkan dari dalam ke luar dengan posisi tangan lurus ke samping kiri. Peupeuh tangan kiri, gerak jatuhan tangan kiri dari atas ke bawah. Guntingan, gerak kedua tangan menyilang di depan muka dengan posisi badan doyong ke belakang dan posisi kedua kaki rengkuh kemudian kedua tangan menangkis silang. Peupeuh dua tangan, gerak peralihan dari posisi kedua lengan melipat di muka kemudian ditarik menyilang ke belakang lurus pundak, kedua tangan menebas ke bawah. Pasang sogok, gerak kaki kuda-kuda kanan depan, kaki kiri di belakang, posisi badan doyong ke depan, dan posisi tangan kiri menusuk telungkup dan tangan kiri terbuka disimpan di pinggang.

Pola isi atau pola tengah selanjutnya disebut pola empat pencugan ibing penca, terdiri atas jurus pasang sogok kanan, pasang sogok kiri, rogok, jambret, luncat malik/ kelid, dan pasang tungkup. Uraian jurus dimulai dari pasang sogok kanan merupakan gerak tangan kanan maju ke depan bersamaan dengan menarik tangan kiri (berlawanan arah). Pasang sogok kiri, merupakan gerak tangan kiri maju ke depan bersamaan dengan menarik tangan kanan (berlawanan arah) gerakan pasang sogok ini tujuannya untuk menyerang bagian tubuh lawan. Rogok, gerakan dilakukan ke dua tangan ke atas di samping leher. Jambret, gerak tarikan kedua tangan ke atas mengarah ke arah badan kita. Luncat malik merupakan gerakan loncatan kaki kiri dan kanan ke belakang kemudian badan memutar ke arah kiri. Pasang tungkup merupakan gerak langkah kaki kanan serong kanan depan bersamaan dengan gerakan tangan kanan menelungkup ke depan.

Pola akhir atau pola lima pencugan ibing penca, terdiri atas jurus pasang sogok, rogok, meulit kacang, giwar, dan pasang nanggeuy. Uraian jurus dimulai dari pasang sogok merupakan gerak pasang posisi tangan kiri menempel paha, tangan kanan depan terbuka telungkup dan posisi kaki kanan di depan lurus dan kaki kiri lurus di belakang. Rogok, gerakan tangan mundur ke belakang langsung bergerak ke depan seolah-olah menusuk lurus. Meulit kacang, gerak peralihan tangan rogok ditarik melipat ke belakang, tangan kiri dibuka lurus dada, tangan kiri dibuka lurus dada ke samping. Geblig, gerakan kaki kanan menghentak lurus dengan kaki kiri, posisi badan tegak dengan kedua tangan mengepal di pinggang. Giwar, gerak tangkisan tangan kanan ke bawah untuk menangkis tendangan kaki. Tangkisan kanan tersebut mengarah dari dalam keluar. Pasang nanggeuy, gerak pasang dengan posisi tubuh tegak dan kedua tangan terbuka seolah memikul beban dan posisi kaki kanan ditekuk ngambang serong dan posisi kaki kiri tegak lurus menapak tanah.

Pola pencugan ibing penca Topeng Pendul dengan ragam jurus, kehadirannya tidak dapat lepas dari pengaruh beberapa aliran pencak silat dan ibing pencak yang tumbuh dan berkembang di Jawa Barat, yakni silat Cimande, silat Cikalong, ibing penca tepak dua dan tepak tilu paleredan.

Analisis hasil temuan terkait pola dan ragam jurus dalam pencugan ibing penca Topeng Pendul pimpinan Bapak Syahrul Kabupaten Karawang dengan kandungan jurus atau gerak aliran pencak silat dan ibing pencak di Jawa Barat dapat dilihat pada tabel 2.

Tabel 2. Kandungan jurus atau gerak aliran pencak silat dan ibing pencak di Jawa Barat.

\begin{tabular}{cl}
\hline No. & \multicolumn{1}{c}{ Pencak Silat dan Ibing Pencak } \\
\hline 1 & Silat Cimande: \\
& Jurus kelid dan jurus pepedangan Ci- \\
& mande. Jurus kelid Cimande; serong \\
& panggul dan beulit kacang \\
2 & Silat Cikalong: \\
& Pertama, jurus sambut pada bagian \\
& sambut tengah (rawel) dan sambut da- \\
& lam (tangkis dua tangan). Kedua, jurus \\
\hline
\end{tabular}


Tabel 2. Kandungan jurus atau gerak aliran pencak silat dan ibing pencak di Jawa Barat. (lanjutan)

\begin{tabular}{cl}
\hline No. & \multicolumn{1}{c}{ Pencak Silat dan Ibing Pencak } \\
\hline 2 suliwa dalam gerakan suliwa kaki ka- \\
nan melangkah tangan kiri merogok \\
atau kaki kiri melangkah tangan kanan \\
merogok dan jurus lipet potong, gerak- \\
an menangkap serangan tangan lawan, \\
dilipat menjadi patahan. Ketiga, gerak \\
pancer, pada pancer satu, posisi kuda \\
- kuda sebagai tumpuan badan dengan \\
langkah kaki melakukan gerak tangan \\
dan putaran balik badan 90 derajat. \\
Keempat, gerak tangtungan kembar, \\
posisi kedua kaki sejajar dan kedua ta- \\
ngan mengepal di dada. \\
Ibing pencak tepak dua paleredan: \\
Jurus Tepak dua paleredan dengan jurus; \\
kuda-kuda serong (langkah kaki kiri, \\
langkah kaki kanan, pasang tangan \\
kanan serong kiri). sogok, giles, sodok \\
jambret, gejlig, peupeuh, sogok. \\
Ibing Pencak Tepak tilu paleredan: \\
Tepak tilu paleredan dengan jurus; lang- \\
kah kaki kanan, kiri, pasang (kedua \\
lengan di depan dada), gunting (kaki \\
dibuka sejajar), giles, sogok, peupeuh, ge- \\
jlig, dan luncat. \\
\hline
\end{tabular}

Adapun analisis pengaruh jurus pencak silat dan ibing pencak terhadap pencugan ibing penca Topeng Pendul Kabupaten Karawang dapat dilihat pada tabel 3.

Tabel 3. Analisis pengaruh jurus pencak silat dan ibing pencak terhadap pencugan ibing penca Topeng Pendul pimpinan Bapak Syahrul Kabupaten Karawang.

\begin{tabular}{cl}
\hline No. & \multicolumn{1}{c}{ Pencugan Ibing Penca } \\
\hline 1 & $\begin{array}{l}\text { Pola dua meulit kacang dan pola lima } \\
\text { pada jurus meulit kacang, giwar dan pa- } \\
\text { sang nanggeuy. }\end{array}$ \\
$2 \quad \begin{array}{l}\text { Pola empat pada jurus jambret dan pola } \\
\text { tiga pada jurus silang tangkis. }\end{array}$ \\
$3 \quad \begin{array}{l}\text { Pola dua, tiga empat dan adanya jurus } \\
\text { rogok dan pola tiga pada jurus lipat po- } \\
\text { tong. }\end{array}$ \\
$4 \quad \begin{array}{l}\text { Pola empat pada jurus luncat malik. } \\
5\end{array}$ \\
$\begin{array}{l}\text { Pola satu jurus bukaan atau kuda-kuda } \\
\text { kaki dengan jurus; kuda-kuda langkah } \\
\text { pinggang. }\end{array}$ \\
$\quad \begin{array}{l}\text { Pola satu dengan jurus; } k \text { knda-kuda lang- } \\
\text { kah 1,2 dan 3, gebrig dan pasang sogok. }\end{array}$ \\
\hline
\end{tabular}

Tabel 3. Analisis pengaruh jurus pencak silat dan ibing pencak terhadap pencugan ibing penca Topeng Pendul pimpinan Bapak Syahrul Kabupaten Karawang. (lanjutan)

\begin{tabular}{cc}
\hline No. & \multicolumn{1}{c}{ Pencugan Ibing Penca } \\
\hline 6 & Pola dua dengan jurus; pasang sogok, \\
& giles, rogok, giwar, dan pasang nanggeuy. \\
& Pola tiga, dengan jurus; pasang sogok, \\
& silang tangkis, peupeuh bawah, pasang \\
& sogok, giwar tangan kiri, peupeuh tangan \\
& kiri, guntingan, peupeuh dua tangan dan \\
& pasang sogok. Pola empat dengan jurus; \\
pasang sogok kanan, pasang sogok kiri, & rogok, jambret, dan luncat. Pola lima \\
& dengan jurus; pasang sogok dan rogok. \\
7 Pola satu jurus bukaan atau kuda-kuda \\
kaki dengan jurus; kuda-kuda langkah \\
1,2 dan 3. Posisi tangan mengepal di \\
pinggang. Pola dua dengan jurus pa- \\
sang sogok, dan giles. Pola tiga dengan \\
jurus pasang sogok kanan, peupeuh dan \\
guntingan. Pola empat dengan jurus pa- \\
sang sogok kanan, pasang sogok kiri, dan \\
luncat malik. Pola lima dengan jurus pa- \\
sang sogok, geblig kaki kanan dan giwar.
\end{tabular}

Mengacu hasil analisis unsur jurus aliran pencak silat Cimande, Cikalong dan jurus ibing penca tepak dua dan tepak tilu paleredan terhadap pencugan ibing penca Topeng Pendul Kabupaten Karawang dapat dikatakan mendapat pengaruh kuat.

Kuatnya pengaruh ragam jurus aliran pencak silat dan ibing pencak di Jawa Barat terhadap pencugan ibing penca Topeng Pendul, dikarenakan, pertama, adanya peran pesantren sebagai lembaga pendidikan masyarakat dan pusat latihan bela diri dalam perjuangan kemerdekaan. Kedua, letak geografis yang berdekatan, yakni Bogor dan Cianjur, menimbulkan persebaran ke daerah Bekasi dan Karawang. Ketiga, antusiasme pelaku seni dalam mempelajari pencak silat sebagai alat pertahanan diri dari gangguan orang jahat dalam pentas keliling.

\section{Unsur Pertunjukan Pencugan Ibing Penca Topeng Pendul.}

Unsur-unsur pertunjukan pencugan ibing penca Topeng Pendul sebagai wujud pem- 
bentuk seni menurut pendapat Taryana (wawacara, 28 Februari 2016) memiliki unsur: (1) waktu, (2) tempat, (3) lakon, (4) seni peran, (5) musik dan syair lagu, dan (6) rias busana.

\subsection{Unsur Waktu}

Waktu pertunjukan babak lakon Topeng Pendul, biasanya dipentaskan pada acara hajatan pernikahan, khitanan, atau pun acara adat dalam pergantian musim bertani. pementasannya dilakukan pada malam hari di tengah lapang dengan perkiraan mulai dari pukul 24.00 WIB. sampai dengan pukul 03.00. WIB.

\subsection{Unsur Tempat}

Tempat pertunjukan Topeng Pendul dilakukan di arena terbuka, di tengah lapang dan selalu menghadap arah mata angin ke arah Selatan. Dengan alasan bahwa Selatan itu memiliki watek duniawi agar mendapatkan rizki banyak, terutama mendapat saweran dari para simpatisan dan penonton.

Setting pementasan pada babak lakon, berubah dengan menghilangkan kotak tempat menyimpan sesaji yang diganti dengan sepasang kursi kanan kiri mengapit meja besar, ditempatkan di tengah-tengah arena pertunjukan dengan posisi di hadapan para wiyaga (penabuh) Topeng Pendul. Fungsi meja dan kursi sangat efektif sebagai simbol peralatan penunjuk identitas tempat kejadian dalam membangun peristiwa lakon, apakah itu kejadian di Balai Desa, di rumah, di tempat Jawara atau gardu ronda dan penunjuk tempat kejadian lainnya. Terkait bahan kursi atau meja, dalam hal pertunjukan tidak menjadi masalah karena sangat tergantung dari kondisi apa adanya dari barang yang tersedia di tempat pertunjukan.

\subsection{Unsur Lakon}

Lakon pada Topeng Pendul pada dasarnya merupakan pertunjukan drama. Pokok dari drama adalah konflik dengan tema tertentu yang tidak lepas dari roman sejarah dan kisah keluarga.
Lakon dibawakan dengan bahasa verbal dan nonverbal, melalui; gesture tubuh, ekspresi wajah dan kata-kata oleh pemeran, baik dengan cara berdialog maupun monolog.

Lakon yang dipentaskan dapat digolongkan pada cerita melodramatis, dengan tema-tema lakon mengisahkan tokoh yang berbuat jahat, harus menerima hukuman atau sebaliknya tokoh baik berujung mendapat kemenangan dan bahagia.

Ketentuan lain dalam membawakan lakon, mereka sama sekali tidak berani untuk mengubah nama tokoh atau mengganti nama dari suatu tempat. Ketentuan ini, mereka lakukan untuk menjaga keutuhan dan keakuratan lakon terhadap para keturunannya yang masih hidup di daerah Karawang dan sekitarnya. Apabila terjadi kekeliruan dalam membawakan lakon terutama cerita roman sejarah maka dapat terjadi penuntutan perkara dari para keturunannya kepada rombongan Topeng Pendul.

\subsection{Unsur Seni Peran}

Unsur seni peran dalam pertunjukan Topeng Pendul dapat dibagi dalam lima peran, yaitu sebagai penari, sinden, dalang, penabuh gamelan, dan pemeran lakon.

Lakon dibawakan oleh para pemerannya dilakukan tanpa naskah utuh (bagal, garis besar lakon), memiliki kecenderungan memberikan kebebasan bagi para pemeran untuk melakukan spontanitas gerak dan improvisasi dialog serta pengembangan blocking agar lebih leluasa. Setiap pemeran memiliki kemampuan tipe casting dan bersifat pengulangan terhadap peran yang dibawakan, maka proses tersebut memberikan penguatan agar setiap penampilan dalam membawakan peran lakon tetap prima.

Dominannyatema-temalakonkekerasan berakar dari roman sejarah, berdampak pada pertunjukan lakon menjadi ajang unjuk keterampilan ibing penca, bermain golok, menguji kekebalan tubuh melalui adegan dalam membawakan karakter peran sebagai tokoh protagonis dan atau antagonis. 


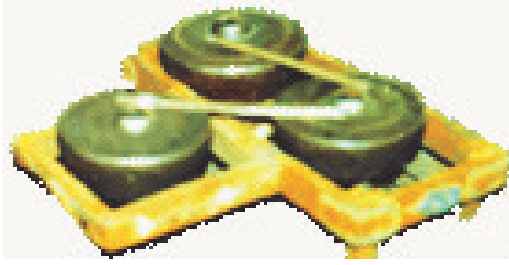

Ketuk

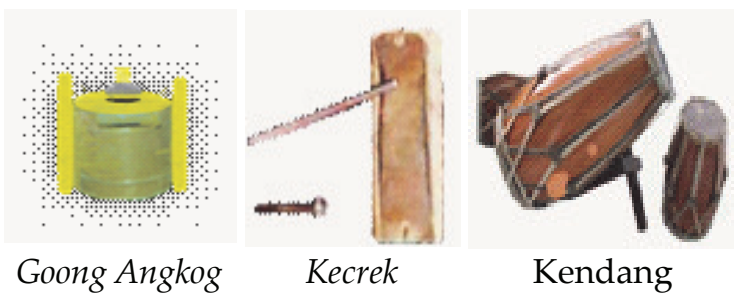

Gambar 1. Waditra pengiring pencugan ibing penca (Dokumentasi peneliti, 28 Agustus 2016)

\subsection{Unsur Musik dan Syair Lagu}

Musik sebagai unsur pembentuk seni memiliki sarana ungkap bunyi. Unsur bunyi yang dihasilkan sumber dan peralatan bunyi berupa benda dan suara dilakukan dengan teknik membunyikan, sehingga menghasilkan irama bunyi yang dihendaki dalam rangkaian struktur bunyi.

Babak lakon merupakan salah satu bagian dari struktur pertunjukan Topeng Pendul dalam hubungan penyajian musik. Lakon selalu diawali dengan lagu pengantar secara khas yakni lagu trembel. Lagu trembel merupakan lagu perpaduan antara tabuhan musik berirama kliningan dan lantunan Juru Sinden. Ia berfungsi sebagai interval atau penyelang para pemain dalam mempersiapkan pementasan lakon.

Gamelan atau waditra yang digunakan dalam babak lakon Topeng Pendul berlaras salendro dengan alat gamelan; kendang besar dan dua buah kulanter (kendang kecil), keset atau rebab, goong angkog (ciblon), ketuk tiga buah, dan kecrek. Untuk lebih jelasnya dapat dilihat pada gambar 1.

4.6. Unsur Rias dan Busana

Rias dan busana pertunjukan lakon Topeng Pendul dapat dikatakan bersifat keseharian. Rias wajah yang dipergunakan

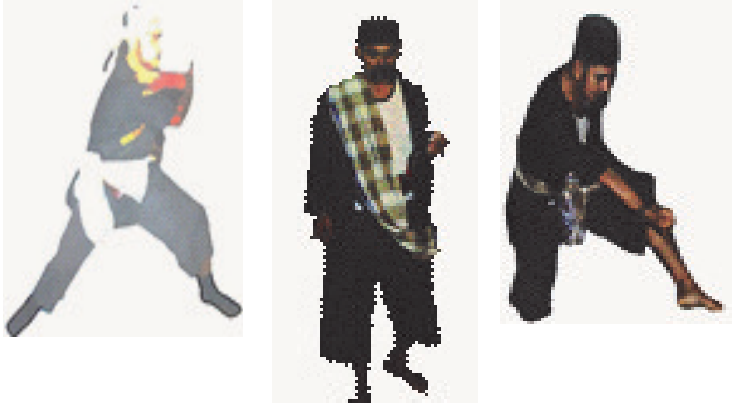

Gambar 2. Rias busana pencugan ibing penca (Dokumentasi grup Topeng Pendul, 2015)

yaitu sebagai penguat karakter tokoh, baik tokoh hitam (tokoh jahat), tokoh putih (tokoh baik), maupun pemeran tokoh lainnya. Wakil pemerintah, pemeran perempuan dilakukan mengandalkan makeup berbahan bedak saripohaci, lipstik, pensil alis, jelaga atau arang, dilakukan di tengah berlangsungnya pertunjukan.

Busana pemeran Topeng Pendul didesain berdasarkan kisah keluarga dan atau roman sejarah. Misalnya, pakaian dengan stelan seragam wakil pemerintah desa, aparat keamanan dengan seragam dinas militer, ibu rumah tangga dengan kebaya, kain samping, selendang atau dengan pakaian rok terusan. Begitu pula para tokoh hitam, pendekar lengkap dengan stelan pangsi dan celana kampret berwarna hitam tanpa alas kaki dengan asesoris sabuk lebar dan golok tersimpan di pinggang. Gambar rias dan busana pencugan ibing penca Topeng Pendul dapat dilihat pada gambar 2.

\section{Fungsi Pertunjukan}

Pencugan ibing penca Topeng Pendul Kabupaten Karawang memiliki fungsi sebagai media hiburan estetis. Artinya, masyarakat penanggap maupun masyarakat penonton pertunjukan merasa terhibur bahkan terlibat dalam aksi saweran. Saweran yang dimaksud berupa pemberian uang dari penonton secara suka rela, karena penonton merasa terpukau melihat penampilan tokoh protagonis dan atau antagonis ketika menampilkan pencugan ibing penca 
pada adegan awal babak lakon sebelum menyampaikan kata-kata (monolog) dengan penonton (aside).

Pertunjukan pencugan ibing penca Topeng Pendul pun memliki fungsi sebagai penghormatan dan bangga terhadap para leluhurnya. Rasa hormat dan bangga terhadap para leluhurnya merupakan ungkapan penanggap pertunjukan atas permintaan lakon kepada rombongan kesenian dengan kecenderungan lakon roman sejarah.

Pencugan ibing penca Topeng Pendul memiliki fungsi sebagai penguat karakter tokoh putih dan atau tokoh hitam dalam membawakan lakon roman sejarah. Lakon roman sejarah cenderung dikaitkan dengan keluhuran budi atau keluhungan ilmu bela diri, yakni pencak silat yang identik dengan pendekar atau tokoh masyarakat atau pemuka agama yang dibekali dengan ilmu silat. Masa sebelum dan setelah kemerdekan Indonesia banyak terjadi kerusuhan, kegentingan, dan kekacauan dari ulah para penjahat atau para begal, oteng-oteng atau pengganggu keamanan masyarakat.

\section{SIMPULAN}

Pencugan ibing penca pada kesenian Topeng Pendul pimpinan Syahrul di Kabupaten Karawang hingga kini dapat dikatakan masih menyimpan bentuk seni sesuai aslinya sebagaimana amanah para leluhurnya. Manakala tidak berpegang teguh pada amanah yang diberikan para leluhurnya, dirinya (pemilik, penerus dan pelaku seni) merasa durhaka dan berdosa kepada orang tua.

Rasa hormat dari sikap teladan yang telah dicontohkan para leluhurnya, terutama para tokoh, para jawara masyarakat Karawang dan Bekasi yang telah turut berjuang dalam melawan penjajahan Belanda berdampak pada hadirnya pencugan ibing penca pada babak lakon pertunjukan topeng banjet bertemakan roman sejarah.

Sejatinya pencugan ibing penca dan tetap bertahannya kesenian topeng banjet hingga kini di Kabupaten Karawang tidak lepas dari adanya hubungan emosional yang saling mengikat antara masyarakat pemilik (pelaku) seni dan pendukung (penikmat) seni di tengah-tengah generasi penerusnya.

\section{Ucapan Terima Kasih}

Rasa syukur dan ketulusan hati peneliti sampaikan terima kasih kepada Lembaga Penelitian dan Pengabdian kepada Masyarakat (LPPM) UPI yang telah memberikan bantuan dana penelitian Non-PNBP TA. 2016 skim Penelitian Penguatan Kompetensi. Tidak lupa kami sampaikan pula terima kasih kepada kelompok seni Topeng Pendul Kabupaten Karawang, pimpinan Bapak Syahrul, Bapak Sangkun Taryana selaku sesepuh, pemeran tokoh dan dalang topeng, Ibu Suhayati selaku pemeran tokoh, pelatih tari, dan penari topeng banjet dan semua pihak yang tidak kami sebutkan satu persatu.

\section{Daftar Pustaka}

Creswell, J. W. (2010). Research Design, Pendekatan Kualitatif, Kuantitatif dan Mixed. Yogyakarta: Pustaka Pelajar.

Iramaya, N., Rosala, D., \& Supriyatna, A. (2015). Ibing Pencak Kesenian Topeng Pendul Kabupaten Karawang." Skripsi (S1) Program Pendidikan Seni Tari, FPSD UPI.

Jaeni. (2012). “Komunikasi Estetik dalam Seni Pertunjukan”. Panggung, 22 (2), 160-168. doi: 10.26742/ panggung. v22i2.58.

Kasmahidayat, Y., \& Sumiyati, I. (2010). Ibing Pencak Sebagai Materi Pembelajaran. Bandung: CV. Bintang WarliArtika.

Kuswandi, A. Penca Silat Jabar. Retrieved February 2014, from http://www. Penca.silatjabar.

Mulyana, E., \& Ramlan, L. (2012). “Keser bojong: Idealisasi Pencitraan Jaipongan Karya Gugum Gumbira." Panggung, 22 (1), 37-51. doi: 10.26742/ panggung. v22i1.34 
Saepudin, A. (2013). “Konsep dan Metode Garap dalam Penciptaan Tepak Kendang Jaipongan". Panggung, 23 (1), 19-30. doi:10.26742/ panggung. v23i1.84

Wikandia, R. (2016). "Pelestarian dan Pengembangan Seni Ajeng Sinar Pusaka pada Penyambutan Pengantin Khas Karawang". Panggung, 26 (1), 58-69. doi:10.26742/panggung. v26i1.162

Soleh, R.H.O. (2010). Silat Tradisional Maenpo Cikalong. Malang: Buih Leba.
Supriyatna, A. (2010). Topeng Baskom Kabupaten Karawang, Kajian Kesinambungan dan Perubahan dari Tahun 1964 Sampai dengan 2010. Bandung: Sekolah Pascasarjana Universitas Pendidikan Indonesia, Program Pendidikan Seni S2.

Wikipédia. (2016). Silat Cimande. Retrieved from Wikipedia bahasa Indonesia, ensiklopedia bebas: https:// id. wikipedia. org/wiki/Silat_Cimande. 